R E S E A R C H A R T I C L E

\title{
Effect of Croton caudatus Geiseler Aqueous Root Extract on Reproductive and Biochemical Parameters in Male Wistar Rats
}

\author{
Razif Dasiman ${ }^{1,2 *}$, Mastura Abd Malek ${ }^{2}$, Ebby Anuar Bahari ${ }^{1}$, Fatin Nadzirah Zakaria',2, \\ Nina Keterina Hashim ${ }^{1,2}$, Afiqah Samsudin ${ }^{1}$, Kamalru Azman Daud ${ }^{1}$, Fatimah Sham ${ }^{1,2}$, \\ Zulkhairi Amom ${ }^{1}$
}

\begin{abstract}
${ }^{1}$ Faculty of Health Sciences, Universiti Teknologi MARA, Selangor Branch, Puncak Alam Campus, 42300 Puncak Alam, Selangor, Malaysia ${ }^{2}$ Maternofetal and Embryo Research Group (MatE), Faculty of Medicine, Universiti Teknologi MARA, Selangor Branch, Sungai Buloh Campus, 47000 Sungai Buloh, Selangor, Malaysia

*Corresponding author. E-mail: razifdasiman@gmail.com
\end{abstract}

Received date: Feb 28, 2020; Revised date: Jul 22, 2020; Accepted date: Jul 24, 2020

\section{Abstract}

B ACKGROUND: Croton caudatus Geiseler (CCG), a local herb that empirically has been used as traditional medicine for malaria, fever, convulsions, and rheumatic arthritis. This study aimed to investigate the effect of CCG on reproductive and biochemical parameters in male Wistar rats.

METHODS: Twenty-four Wistar male rats were divided randomly into four groups, which were treated with CCG aqueous root extract at the concentration of $0-16 \mathrm{mg} / \mathrm{kg}$, via oral gavage. After 21 days of treatment, blood, sperm, and testes were harvested for analyses. Sperm parameters were evaluated using computer-assisted sperm analyser (Hamilton Thorne Sperm Analyzer), and morphometric analyses of histological changes were performed.

RESULTS: CCG extract at 8 and $16 \mathrm{mg} / \mathrm{kg}$ significantly $(p<0.05)$ increased the total sperm count, concentration, and motility; whereby, only $16 \mathrm{mg} / \mathrm{kg}$ significantly decreased the percentage of abnormal sperm morphology. Testosterone hormones levels were the highest in $4 \mathrm{mg} / \mathrm{kg}$ CCG but were slightly decreased in 8 and $16 \mathrm{mg} / \mathrm{kg} \mathrm{CCG}$. The histological results showed a significant increase in the germinal epithelial height, decrease of lumen size at $16 \mathrm{mg} / \mathrm{kg}$ of CCG extract. No significant changes of alanine aminotransferase (ALT) and creatinine levels in serum from all CCG extract groups. However, the aspartate aminotransferase (AST) level in $8 \mathrm{mg} / \mathrm{kg}$ CCG was elevated, and the blood urea nitrogen (BUN) level was decreased in all CCG extract groups.

CONCLUSION: In conclusion, the CCG extract at $4 \mathrm{mg} / \mathrm{kg}$ has the potential to enhance spermatogenesis activity within the seminiferous tubules in rats without any hepatotoxicity and nephrotoxicity effect on the liver and kidney.

KEYWORDS: Croton caudatus Geiseler, rats, spermatogenesis, seminiferous tubules, testis, testosterone

Indones Biomed J. 2020; 12(3): 251-60

\section{Introduction}

Wanted Total Fertility Rate (WTFR) has decreased dramatically in the last few decades, with rates falling on average from 2.8 in 1970 to 1.7 per woman childbearing rates in 2016. Countries most affected by declining fertility rates, such as Australia, New Zealand, Spain, and the United States of America.(1) Indeed, overall fertility rates in Asia have been reported at or below the replacement level, which is 2.1 per woman, particularly in Japan, South Korea, and
Singapore.(1) The United Nations has issued an estimation of WTFR based on their report in which the levels will continue to decline towards 2050.(2)

Infertility is a reproducible illness that causes the inability to get pregnant after 12 months or more of regular unprotected sexual intercourse according to the International Committee for the Monitoring of Assisted Reproductive Technology (ICMART) and the World Health Organization (WHO).(3) Infertility is a global problem affecting one in ten couples.(4) Women may traditionally be held responsible for infertility because of their incapacity to 
conceive. Nonetheless, a study reported that $50 \%$ of male partners contributed infertility due to low sperm counts and poor sperm quality, or both.(5,6) Men's health should, therefore, be given importance and attention to prevent deterioration in sexual dysfunction.

Male infertility can be caused by many causes, such as hormonal imbalances, drug abuse, depression, anxiety, and stress. Besides, certain medical conditions, like diabetes and coronary heart disease, toxic substances, chemicals, and pollution, cause male infertility.(7-9) In contrast, male sexual problems can be treated naturally, and that is the best way to treat male infertility. More attention has been paid in recent years to traditional herbs and plants with high antioxidants, which are essential for protecting cells from oxidative damage. $(10,11)$ Antioxidants from plants act by donating a hydrogen atom, catalyzing oxidative processes and scavenging oxygen, absorbing UV radiation, inhibiting enzymes or decomposing hydroperoxides.(12) Therapeutic plants have been utilised experimentally as extracts, decoctions, fractions, or half-purified compounds.(13) Progress in phytomedicine has made it possible to treat disease as well as human infertility more efficiently and cost-effectively.(14)

Plants and herbs provide an affordable treatment option for infertile couples who have had sexual problems, such as libido dysfunction, sexual asthenia, erection difficulties, and sperm disorders. Some herbal formulations are recommended as a natural fertility and infertility treatment, some of which are cinnamon, ginseng and Tongkat Ali, which are thought to have a positive effect on sperm motility. In contrast, the mucilage of the Aloe leaf has anti-fertility effects on the reproductive system.(15-17) Herbal remedies can help the production of sperm, increase libido and improve sexual endurance in men.(11) Herbal products are still used anarchically in many regions and countries, and there has been no scientific assessment for a high proportion of medicinal plants traditionally used to resolve men's reproductive disorders.

Euphorbiaceae family phytochemical characteristics have been reported to have excellent antibacterial, antiinflammatory, anti-cancer and antioxidant properties. $(18,19)$ Within the Euphorbiaceae, the local folklore reports that Croton caudatus Geiseler (CCG) or in Malaysian known as Tukul Takal, has anti-fertility effects in females and mostly used during confinement.(20,21) The use of CCG extracts also adversely affected follicle maturation and ovulation in females.(20) However, the infusion of boiled CCG root extract was used as nutrition by the Orang Asli in Perak, West Malaysia.(22) The ethanolic leaf extract of CCG showed antioxidative properties with highly significant activity of reactive hydroxyl scavenging and total antioxidant activity decreased the level of reactive oxygen species (ROS) generated in the stress response system of Saccharomyces cerevisiae model system.(23) Apart from this, CCG also used in the treatment of arthritis, pain relief, stomach disease treatment (24), antidiabetic, and antimalarial treatment (18).

To date, the least information is available on the effects of CCG on spermatogenic activities that can be potential use for infertility treatment in men. Sperm parameters, hormonal status and histological aspects could provide better insight and understanding of the fertility-enhancing properties of the plants. This is the first research that explores CCG's effect on reproductive and biochemical parameters of male Wistar, based on our best knowledge. This study aims to assess the effects of Croton caudatus Geiseler on reproductive and biochemical parameters in male Wistar rats.

\section{Methods}

\section{Plant Material Collection}

Roots of CCG were collected from Kampung Lubok Batu, Rompin, Pahang, Malaysia $\left(2^{\circ} 29^{\prime} 19.7^{\prime \prime N} 102^{\circ} 48^{\prime} 35.2^{\prime \prime E}\right)$ and the authentication of CCG (KLU 47821) was carried out in the herbarium of the Rimba Ilmu Botanical Garden, Institute of Biological Sciences, University of Malaya, Kuala Lumpur, Malaysia. The voucher material for this study was deposited at the same herbarium.

\section{Plant Aqueous Extraction}

Dried CCG roots were ground and kept in closed bottles. One-hundred gram of roots powder were boiled with $1 \mathrm{~L}$ of distilled water at $100^{\circ} \mathrm{C}$ for 15 minutes. The aqueous extract was filtered and lyophilised with freeze-dryer. A stock solution was prepared and stored at $4^{\circ} \mathrm{C}$ until further used.

\section{Animals and Treatments}

Twenty-four male Wistar albino rats with the average age of 10-week-old were obtained from the Laboratory Animal Facility and Management (LAFAM) at Faculty of Pharmacy, Universiti Teknologi MARA (UiTM), Puncak Alam, Selangor, Malaysia. The rats were randomly divided into 4 groups (n=6): (i) Control ( $0.1 \mathrm{~mL}$ of distilled water); (ii) 4 $\mathrm{mg} / \mathrm{kg}$ body weight (BW) of CCG extract; (iii) $8 \mathrm{mg} / \mathrm{kg} \mathrm{BW}$ of CCG extract; and (iv) $16 \mathrm{mg} / \mathrm{kg} \mathrm{BW}$ of CCG extract. The treatments were administered via oral gavage for 21 days. During the experiment, the rats were housed in polyurethane 
cages at of $24 \pm 3^{\circ} \mathrm{C}$, humidity $(50 \pm 5) \%$ in a controlled light environment (12 h light: $12 \mathrm{~h}$ dark) at Laboratory Animal Resource Unit, Faculty of Health Sciences, Universiti Teknologi MARA Puncak Alam, Selangor, Malaysia and provided with water and standard rodents chow pellets ad libitum. This study was approved by the Ethics Committee of Universiti Teknologi MARA, Selangor, Malaysia (UiTM Care: 39/2014).

\section{Collection of Samples}

After 21 days of treatment, the rats were anaesthetised for the collection of blood via cardiac puncture. Then, the rats were euthanised by cervical dislocation. Testes were weighed and fixed in $10 \%$ formalin.

\section{Sperm Parameters Analysis}

The epididymides were removed from testes, weighed and minced separately in $1 \mathrm{~mL}$ of M16 medium (Sigma, Saint Louis, MO, USA) in a petri dish prior incubation in a water bath at $37^{\circ} \mathrm{C}$ for 5 minutes to allow the spermatozoa to swim out.(25) The sperm motility, sperm concentration, and sperm count were evaluated with a Computer-assisted Sperm Analyzer (CASA) system (TOX IVOS, Hamilton Thorne Research, Beverly, MA, USA). The CASA system consisted of a phase-contrast microscope (Zeiss) with a COHU camera system for images captured at 100x magnification. After the incubation process, $4 \mu \mathrm{L}$ sperm samples from each mouse were placed in 2X-Cel Dual-sided sperm analysis chamber (Hamilton Thorne Biosciences, Beverly, MA, USA). The loaded chamber was then placed for analysis at the warm microscope level. The samples were observed by a magnification of 0.78 and by a green filter using $10 x / 0.25$ negative phase contrast area of 10x NC. Several areas of images were captured starting from $2.4 \mathrm{~mm}$ to $29.8 \mathrm{~mm}$ of the stage with minimum numbers of 300 spermatozoa counted for each analysis.

For the assessment of sperm morphology, 1\% Eosin $\mathrm{Y}$ was used. Two drops of Eosin $\mathrm{Y}$ were added into the tube containing sperm suspension and incubated for 45-60 minutes to allow the sperm to absorb the colour of the stain. The percentage of abnormal spermatozoa were assessed on dried smears. Two hundred spermatozoa were evaluated per slide representing $100 \%$. The light microscope was set at $\times 100$ eyepiece magnification.

\section{Histopathological and Morphometric Assessment}

Testes were harvested, weighed, and fixed in 10\% formalin. In increasing sequence of alcohol percentage, the specimens were dehydrated. Tissues were cleaned with xylene and then embedded into paraffin wax. The paraffin-embedded testes were sectioned (thickness, $5 \mu \mathrm{m}$ ), and stained with hematoxylin-eosin (H\&E) for evaluation by light microscopy at $\times 40$ eyepiece magnification (BX51, Olympus Optical Ltd., Tokyo, Japan). Any histological changes of testis include germ cells arrangement disorder, exfoliation, vacuolisation, were observed. For morphometrical analysis, about 50 seminiferous tubules with round or nearly round feature from each mouse were selected randomly and measured diametrically opposite by using Image J software 1.15K (National Institutes of Health, Bethesda, MD, USA). The average was calculated.(26,27)

\section{Biochemical Parameters Analysis}

Five $\mathrm{mL}$ of the whole blood collected from each rat in collection tubes were immediately centrifuged at $2,500 \mathrm{~g}$ for $10 \mathrm{~min}$ at $4^{\circ} \mathrm{C}$, and the serum was stored at $-80^{\circ} \mathrm{C}$ prior to biochemical parameters analysis. Testosterone level was quantified by chemiluminescence in an automated analyser (Cobas E411 Analyzer, Roche Diagnostics, Mannheim, Germany). Alanine aminotransferase (ALT) enzyme and aspartate aminotransferase (AST) enzyme are markers for hepatotoxicity assessment, whereby blood urea nitrogen (BUN) and creatinine are important markers for the evaluation of nephrotoxicity. $(28,29)$ All these hepatotoxicity and nephrotoxicity markers were measured using a biochemistry analyser (Cobas Intergra 400/800 Analyser, Roche Diagnostics, Mannheim, Germany) at Centre for Pathology Diagnostic and Research Laboratories (CPDRL), UiTM Sungai Buloh, Malaysia.

The testosterone level was measured according to the manual of the manufacturer. The testosterone assay was based on a competitive test principle using a monoclonal highaffinity antibody specifically for testosterone. The addition of a testosterone derivative labelled with a ruthenium complex to binding sites on the biotinylated antibody, endogenous testosterone released by 2-bromoestradiol from the sample. The chemiluminescent emission was measured by a photomultiplier.

AST activity was measured according to the International Federation of Clinical Chemistry (IFFC) guidance, without pyridoxal phosphate. $(30,31)$ AST catalyses the conversion of an amino group into oxaloacetate and L-glutamate, including L-aspartate and 2-oxoglutarate in the sample. In the presence of malate dehydrogenase $(\mathrm{MDH})$, the oxaloacetate then reacts with NADH to form $\mathrm{NAD}^{+}$. The NADH oxidation rate is directly proportionate with the catalytic AST activity. The decrease in absorption was determined. 
Kinetic UV assay without pyridoxal phosphate method as suggested by IFFC was used to calculate ALT activity.(32) L-alanine and 2-oxoglutarate are catalysed by ALT. The pyruvate formed is reduced by NADH in a lactate dehydrogenase (LDH) catalysed reaction to form L-lactate and $\mathrm{NAD}^{+}$. The NADH oxidation rate is directly related to the catalytic activity of ALT. The decrease in absorption was assessed.

The BUN in the serum was measured by urease (ammonia absorption) and by dehydrogenase glutamate (to transform ammonia and glutamate into NADH oxidation glutamine). The absorption change regulates the NAD rate at $340 \mathrm{~nm} .(33)$

Creatinine was assessed by Jaffe's reaction where creatinine quantitatively produces the orange colour with alkaline picric acid. The synthesis of creatinine into glycine, formaldehyde and hydrogen peroxide with the aid of creatininase, creatinase and sarcosine oxidase is focused on this method. Peroxidase-catalysed hydrogen peroxide reacts with 4-aminophenazone and HTIB (2,4,6-triiodo-3hydroxybenzoic acid) to form quinone imine chromogenic. The chromogen colour intensity provided by the quinone imine is attributed to the creatinine level in the reaction mix. The colour was measured at $520 \mathrm{~nm}$ following $15 \mathrm{~min}$ incubation at room temperature. $(34,35)$

\section{Statistical Analysis}

Results were expressed as mean \pm standard deviation. Statistical analysis was performed using Graph Pad Prism 7.0 (GraphPad Software, San Diego, CA, USA). For multiple comparisons, ANOVA was used, and post hoc analysis was performed with Tukey's test. Statistical significance at $p<0.05$ was accepted.

\section{Results}

\section{Effect of CCG Supplementation on Body and Testicular} Weight

The CCG affected body weight and testicular weight in rats (Figure 1). Compared with control group, the CCG supplementation caused the body weight (A) of experimental rats to increase significantly with increasing concentrations of CCG root extracts $(4 \mathrm{mg} / \mathrm{kg}=373.3 \pm 6.67$, $8 \mathrm{mg} / \mathrm{kg}=376.7 \pm 6.67,16 \mathrm{mg} / \mathrm{kg}=390 \pm 11.25 v s$. control $=$ $306 \pm 6.00, p<0.05)$. On the other hand, the testicular weight (B), was not significantly different between the control rats and the experimental rats.

\section{Effect of CCG Supplementation on Sperm Parameters}

Various sperm parameters were assessed between the control and experimental groups (Table 1). The total sperm count and sperm concentration in the group supplemented with $8 \mathrm{mg} / \mathrm{kg}\left(172.33 \pm 26.35 \times 10^{6} \mathrm{~m} / \mathrm{L}, 126.93 \pm 19.43 \mathrm{M} /\right.$ $\mathrm{mL})$ and $16 \mathrm{mg} / \mathrm{kg}$ of CCG $\left(150.67 \pm 20.60 \times 10^{6} \mathrm{~m} / \mathrm{L}\right.$, $103.63 \pm 25.44 \mathrm{M} / \mathrm{mL})$ were significantly increased $(p<0.05)$ when compared to the control group $\left(49.67 \pm 6.51 \times 10^{6} \mathrm{~m} / \mathrm{L}\right.$, $36.60 \pm 4.80 \mathrm{M} / \mathrm{mL}$ ). Sperm motility in the $8 \mathrm{mg} / \mathrm{kg} \mathrm{CCG}$ group significantly higher than the control group $(13.6 \pm 1.35$ $\%$ vs. $9.35 \pm 0.83 \%, p<0.05)$. The percentage of abnormal sperm morphology in $16 \mathrm{mg} / \mathrm{kg}$ of $\mathrm{CCG}$ group was significantly decreased $(10.38 \pm 1.11 \%, p<0.05)$ as compared

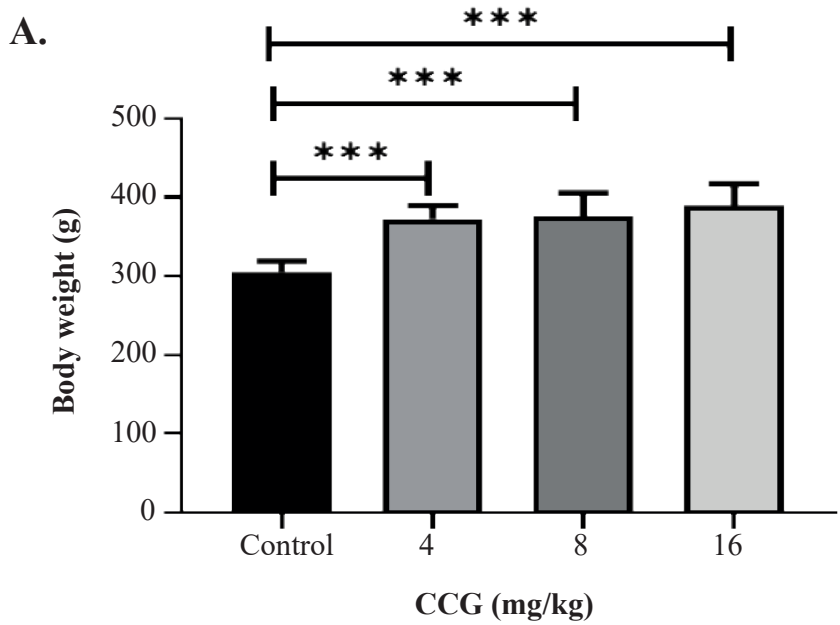

B.

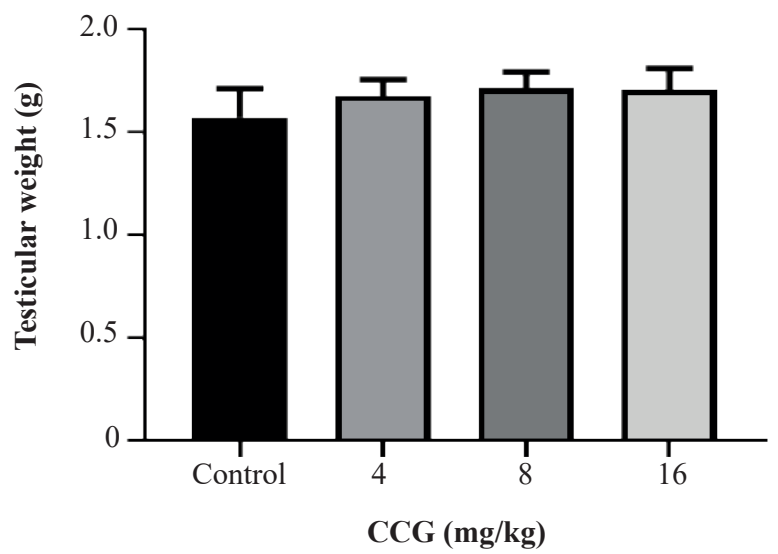

Figure 1. Effect of CCG on body weight (A) and testicular weight (B) of control and experimental rats. Each column represents mean $\pm \mathrm{SD}(\mathrm{n}=6)$. *Indicate data significant at $p<0.05$ with control. 
Table 1. Effect of CCG extract on sperm parameters in male Wistar albino rats (mean $\pm \mathrm{SD})$.

\begin{tabular}{|c|c|c|c|c|c|}
\hline Group & $\begin{array}{l}\text { Sperm Count } \\
\left(\times 10^{6} \mathrm{~m} / \mathrm{L}\right)\end{array}$ & $\begin{array}{c}\text { Sperm Concentration } \\
(\mathrm{M} / \mathrm{mL})\end{array}$ & $\begin{array}{c}\text { Sperm Motility } \\
(\%)\end{array}$ & $\begin{array}{c}\text { Progressive Motility } \\
\text { (\%) }\end{array}$ & $\begin{array}{c}\text { Abnormal Sperm } \\
\text { Morphology } \\
\text { (\%) }\end{array}$ \\
\hline Control & $49.67 \pm 6.51$ & $36.60 \pm 4.80$ & $9.35 \pm 0.83$ & $16.67 \pm 4.51$ & $22.30 \pm 3.03$ \\
\hline $4 \mathrm{mg} / \mathrm{kg} \mathrm{CCG}$ & $62.33 \pm 6.43^{\mathrm{bc}}$ & $44.00 \pm 8.09^{\mathrm{bc}}$ & $10.93 \pm 1.74^{\mathrm{b}}$ & $12.33 \pm 1.53$ & $29.20 \pm 3.65^{* b c}$ \\
\hline $8 \mathrm{mg} / \mathrm{kg} \mathrm{CCG}$ & $172.33 \pm 26.35^{* a}$ & $126.93 \pm 19.43^{* a}$ & $13.63 \pm 1.35^{* a}$ & $70.67 \pm 14.57$ & $18.50 \pm 2.42^{\mathrm{ac}}$ \\
\hline $16 \mathrm{mg} / \mathrm{kg} \mathrm{CCG}$ & $150.67 \pm 20.60^{* a}$ & $103.63 \pm 25.44^{* a}$ & $13.05 \pm 0.63^{*}$ & $49.67 \pm 9.71$ & $10.38 \pm 1.11^{* a b}$ \\
\hline
\end{tabular}

The results are shown as mean $\pm \mathrm{SD}(p<0.05)$. For the analysis of data, one-way ANOVA was used. CCG: Croton caudatus Geiseler. *Indicate data showed significant difference with control; a: significant difference with $4 \mathrm{mg} / \mathrm{kg}$ CCG group; b: significant difference with $8 \mathrm{mg} / \mathrm{kg}$ CCG group; c: significant difference with $16 \mathrm{mg} / \mathrm{kg}$ CGG group.

to all groups of treatment (Table 1). The morphological of normal sperm and various sperm defects were summarized in Figure 2.

\section{Effect of CCG Supplementation on Testicular Histoarchitecture and Morphometric}

In the control group (Figure 3), normal testicular morphology and complete seminiferous architecture were observed in seminiferous tubules with different phases of spermatogonium, spermatocytes and mature sperm. Nonetheless, in contrast to the control group, there have been several structural changes in all CCG groups. The main histopathological changes were noticed, including the increase of sperm cell epithelial height density, lumen reduction with an improved sperm count in CCG groups of $4 \mathrm{mg} / \mathrm{kg}$ and CCG groups of $8 \mathrm{mg} / \mathrm{kg}$. In addition, the lumen was densely filled in the $16 \mathrm{mg} / \mathrm{kg}$ CCG-group with elongated, immature, and mature spermatozoa. (Figure 3).

Morphometrically assessed CCG treatment at $4 \mathrm{mg} / \mathrm{kg}$, $8 \mathrm{mg} / \mathrm{kg}$, and $16 \mathrm{mg} / \mathrm{kg}$ showed no significant alteration in seminiferous tubule diameter as compared with the control group. However, the diameters of the seminiferous lumen were found to be significantly decreased in $16 \mathrm{mg} / \mathrm{kg}$ CCG group compared with the control group $(65.112 \pm 18.32$ vs. $199.84 \pm 20.08, p<0.05)$. The height of the germinal epithelium was also found to be significantly increased in both $8 \mathrm{mg} / \mathrm{kg}$ CCG group (197.02 \pm 25.6 vs. $132.2 \pm 4.96$, $p<0.05)$ and $16 \mathrm{mg} / \mathrm{kg}$ CCG group $(276.77 \pm 43.22 v s$. $132.2 \pm 4.96, p<0.05)$ compared with control. The results of morphometric studies are shown in Table 2.
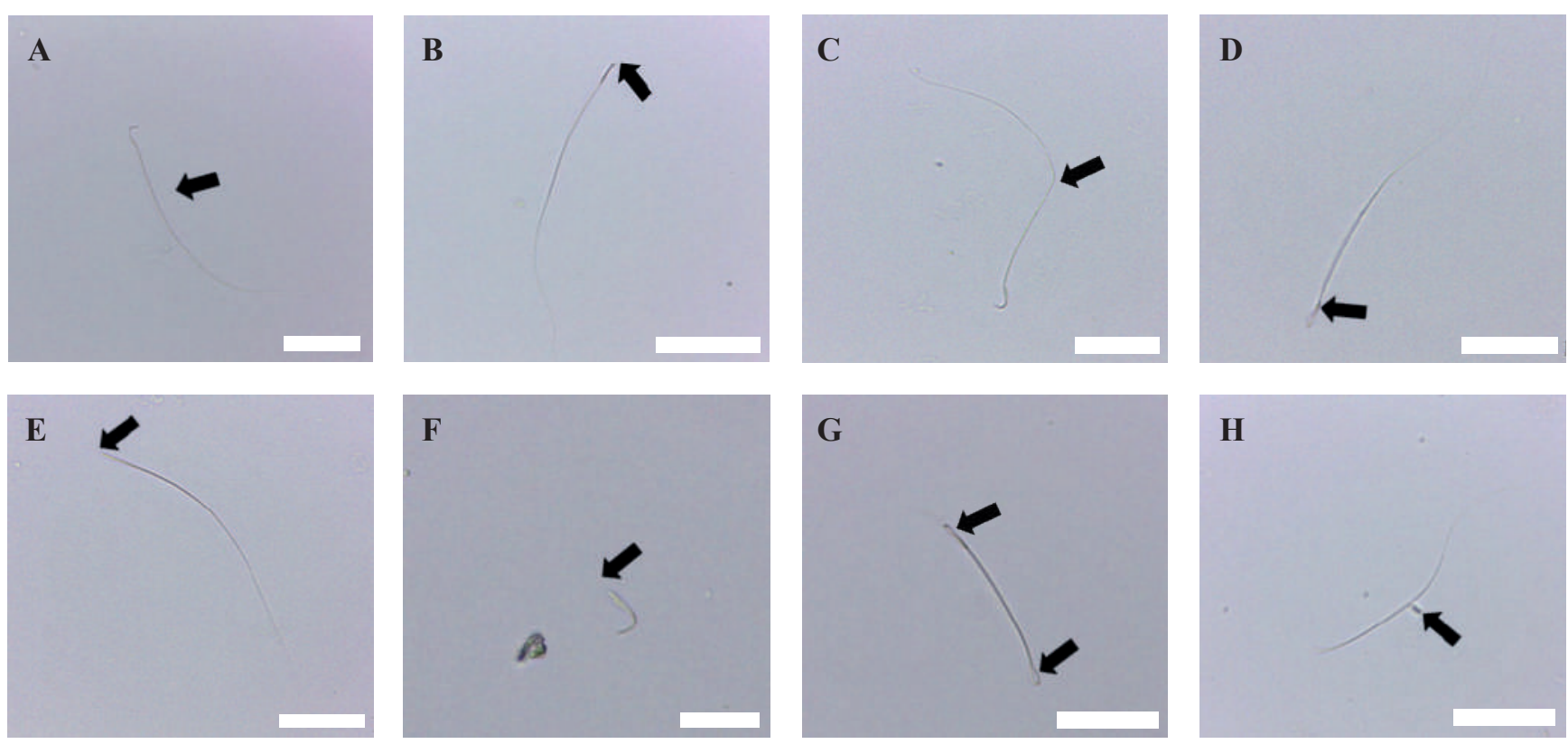

Figure 2. Photomicrographs illustrating normal morphological sperm and various sperm defects after the treatment of CCG roots extract. A: normal, B: abnormal head, C: bent tail, D: cytoplasmic droplet, E: headless, F: tailless, G: pairing phenomenon, H: looped tail. Black arrow: Indicate the defected area. White bar: $200 \mu \mathrm{m}$. 

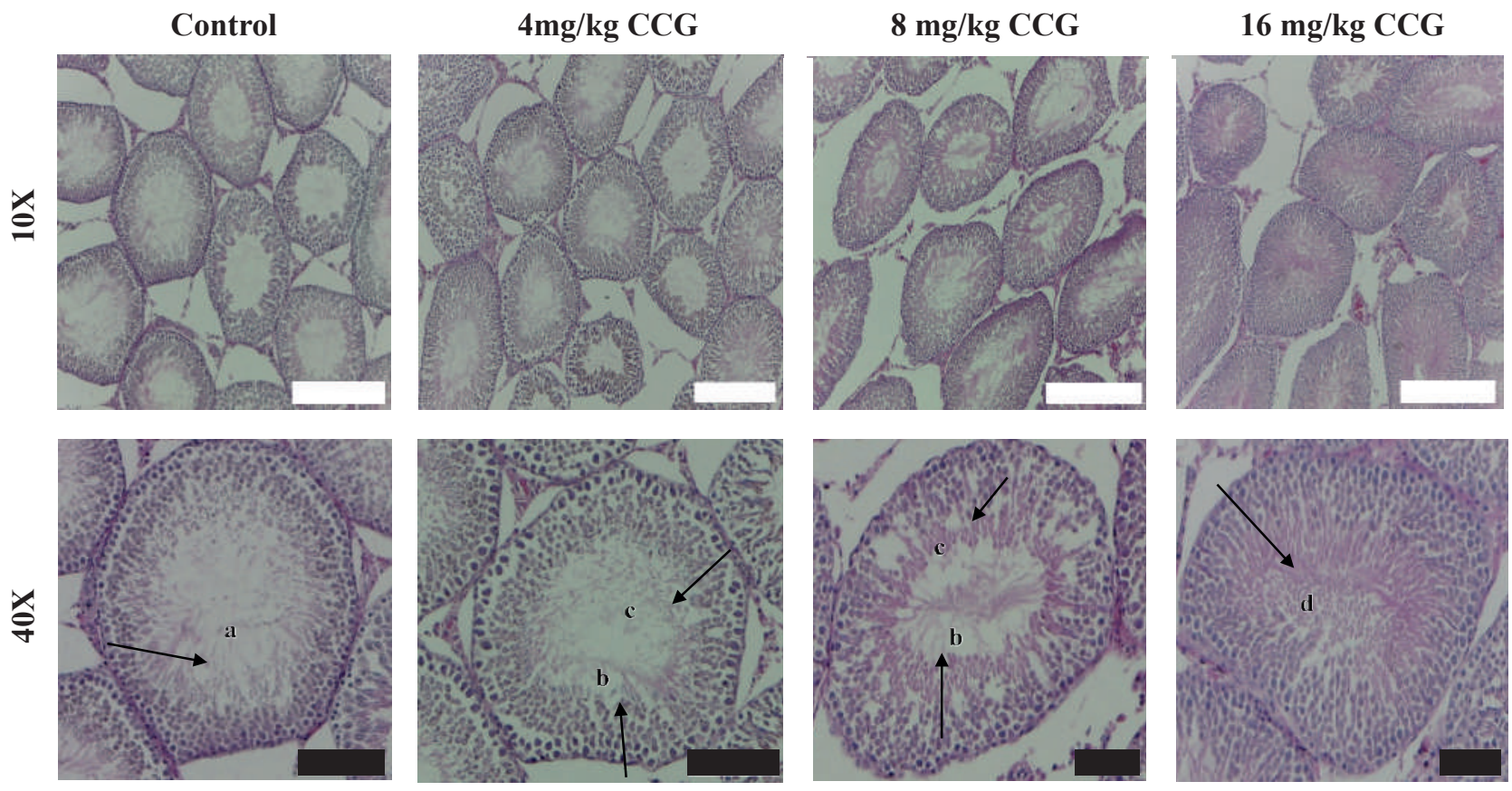

Figure 3. Photomicrographs showing representative seminiferous tubules in rats supplemented with different doses of aqueous extract of Croton caudatus Geiseler (CCG) roots (H \& E Staining). Black arrow: a) Normal seminiferous tubules with a composition of germinal epithelium with sperm cells in the lumen, b) Decrease lumen size with more sperm cells, c) Increase of epithelial height with several spermatogenic layers, d) Lumen compact with a higher density of different stages of spermatogenic cells, elongated spermatids, mature spermatozoa and with complete maturation of germinal epithelium cells. White bar: $1000 \mu \mathrm{m}$; Black bar:200 $\mu \mathrm{m}$.

\section{Effects of CCG on Biochemical Parameters}

Testosterone level in $4 \mathrm{mg} / \mathrm{kg}$ CCG group showed the significantly highest $(46.8 \pm 4.56 \mathrm{nmol} / \mathrm{L}, p<0.05)$ compared to the other groups (Table 3). Furthermore, the lower testosterone level in $8 \mathrm{mg} / \mathrm{kg}(22.47 \pm 3.82 \mathrm{nmol} / \mathrm{L})$ and 16 $\mathrm{mg} / \mathrm{kg}(18.67 \pm 3.16 \mathrm{nmol} / \mathrm{L})$ groups showed a significant increment when compared to control group $(6.63 \pm 1.25$ $\mathrm{nmol} / \mathrm{L}$ ). Effect of CCG root extract on ALT and AST levels in serum was measured. The results showed there are no significant changes in ALT levels observed in 4-16 $\mathrm{mg} / \mathrm{kg}$ CCG group compared to the control group. AST levels decreased significantly in groups of $4 \mathrm{mg} / \mathrm{kg}$ CCG $(120.84 \pm 16.54 \mathrm{U} / \mathrm{L})$ and $16 \mathrm{mg} / \mathrm{kg}$ CCG $(90.73 \pm 13.21$ $\mathrm{U} / \mathrm{L})$. Contrarily, the AST level was higher in $8 \mathrm{mg} / \mathrm{kg}$ of CCG $(348.47 \pm 90.70 \mathrm{U} / \mathrm{L})$ compared to the control group $(243.03 \pm 35.78 \mathrm{U} / \mathrm{L})$. In addition, the serum BUN level in all CCG root extract groups significantly decreased. There were no significant changes observed in creatinine activity in the serum of the treated groups in comparison to the control (Table 3).

\section{Discussion}

Male infertility studies recently focused on improved spermatogenic activity with phytomedicine. Many studies have shown several natural practices that can increase fertility in men significantly.(36) However, there is limited information on the study of traditional Malay herbs, particularly the CCG on male fertility.

Results from this study showed that sperm count, sperm concentration, sperm motility, and testosterone level in all treatment groups were significantly increased, as compared to the control group. Another important indicator of male reproductive health can be sperm concentration and motility, which could directly affect male fertility. These results suggested that the increment on sperm parameters are might be due to the presence of phytochemical compounds in this plant. These findings were consistent with the previous study on CCG leaves, stems and roots, which found that CCG possesses excellent antioxidant properties, rich in flavonoids, saponins, steroids, glycosides, and triterpenoids.(18,37) These phytochemical compounds act as antioxidants, which may serve as free radical scavengers, and enhance sexual activity.(38)

The testicular weight results of this study showed that there was no statistically significant difference between the treatment groups and the control group. The results were in agreement with the previous studies which suggested that the non-significant differences possibly were the result of individual differences in the animal.(39,40) The studies also showed that certain sperm parameters had significant 
Table 2. Effect of CCG extract on seminiferous tubule diameter, seminiferous lumen diameter and germinal epithelial height in male Wistar albino rats (mean \pm SD).

\begin{tabular}{lccc}
\hline Group & $\begin{array}{c}\text { Seminiferous Tubule } \\
\text { Diameter }(\boldsymbol{\mu m})\end{array}$ & $\begin{array}{c}\text { Seminiferous Lumen } \\
\text { Diameter }(\boldsymbol{\mu m})\end{array}$ & $\begin{array}{c}\text { Germinal Epithelial Height } \\
(\boldsymbol{\mu m})\end{array}$ \\
\hline Control & $332.04 \pm 22.06$ & $199.84 \pm 20.08$ & $132.2 \pm 4.96$ \\
$4 \mathrm{mg} / \mathrm{kg}$ & $318.61 \pm 22.7$ & $161.46 \pm 27.02^{\mathrm{c}}$ & $157.14 \pm 32.52^{\mathrm{c}}$ \\
$8 \mathrm{mg} / \mathrm{kg}$ & $364.64 \pm 25.49$ & $167.62 \pm 32.38^{\mathrm{c}}$ & $197.02 \pm 25.6^{{ }^{\mathrm{c}}}$ \\
$16 \mathrm{mg} / \mathrm{kg}$ & $341.88 \pm 28.32$ & $65.112 \pm 18.32^{* \mathrm{ab}}$ & $276.77 \pm 43.22^{*^{\mathrm{ab}}}$ \\
\hline
\end{tabular}

The results are shown as mean $\pm \mathrm{SD}(p<0.05)$. For the analysis of data, one-way ANOVA was used. CCG: Croton caudatus Geiseler. *Indicate data showed significant difference with control; a: significant difference with $4 \mathrm{mg} / \mathrm{kg} \mathrm{CCG}$ group; b: significant difference with $8 \mathrm{mg} / \mathrm{kg}$ CCG group; c: significant difference with $16 \mathrm{mg} / \mathrm{kg}$ CGG group.

differences; however, there were no significant differences in the testicular weight. $(39,40)$ The current study is in line with the previous studies, which showed that there is no impairment in the testicular weight after 21 days of treatments with CCG aqueous roots.

The most reliable method for detecting effects on sperm production is testicular histomorphology.(41) Spermatogenesis disorders can be considered arbitrarily to include qualitative and/or quantitative elements. Leydig cells and their subcell properties, blood vessels, cell invasion, cell membrane, multi-nucleated giant cells, Sertoli cell morphology, missing germ cells, germ cell abnormalities and germ-cell growth are included in the qualitative evaluation. Whereas, the quantitative assessment includes tubular diameter, sperm production determination and morphometric cell numbers. A qualitative test of germ cell histomorphology and a quantitative test using morphometry were carried out.

The testes were sliced cross-sectional and processed to be observed under the microscope. Gelam honey was found to have the potential to enhance spermatogenesis and improves all the sperm parameters.(33) From the histological study, abundant spermatogenic cells in the testes indicate that higher spermatogenesis processes were facilitated by treatment of Gelam honey. In our study, different concentrations were used, which are $4 \mathrm{mg} /$ $\mathrm{kg}, 8 \mathrm{mg} / \mathrm{kg}$, and $16 \mathrm{mg} / \mathrm{kg}$ of CCG roots gave different histological results. The higher concentration of CCG roots extract shows a higher number of spermatogenic cells inside the seminiferous tubule of the testes. Based on the testicular morphometry analysis, it was observed that the lumen diameter decreased, and epithelial germinal cell height increased with increasing doses of CCG. The reason for this could be due to the polyphenolic flavonoid components in CCG root extract, which has antioxidant property as reported by Nath and colleagues.(18) An additional antioxidant is needed to enhance the process of spermatogenesis and germ cell maturation by reducing the oxidative stress level in the testicular. The morphology in the $16 \mathrm{mg} / \mathrm{kg}$ CCG group was indicative of progressive changes in the germinal epithelium that are essential for the process of spermatogenesis, spermiogenesis and synchronisation of germ cell maturation.

Lumen and seminiferous tubule were compact filled with spermatogenic cells in testes treated with CCG roots compared to the control group. Histological examination showed that this plant enhances fertility level of male rats by improving the process of spermatogenesis in the testes.

Table 3. Effect of CCG extract on testosterone and biochemical parameters in male Wistar albino rats (mean \pm SD).

\begin{tabular}{lccccc}
\hline \multicolumn{1}{c}{ Group } & $\begin{array}{c}\text { Testosterone level } \\
(\mathbf{n m o l} / \mathbf{L})\end{array}$ & $\begin{array}{c}\text { Alanine } \\
\text { Aminotransferase } \\
(\mathbf{U} / \mathbf{L})\end{array}$ & $\begin{array}{c}\text { Aspartate } \\
\text { Aminotransferase } \\
(\mathbf{U} / \mathbf{L})\end{array}$ & $\begin{array}{c}\text { Blood Urea Nitrogen } \\
(\mathbf{m m o l} / \mathbf{L})\end{array}$ & $\begin{array}{c}\text { Creatinine } \\
(\boldsymbol{\mu m o l} / \mathbf{L})\end{array}$ \\
\hline Control & $6.63 \pm 1.25$ & $51.26 \pm 6.37$ & $243.03 \pm 35.78$ & $8.47 \pm 1.31$ & $26.50 \pm 1.87$ \\
$4 \mathrm{mg} / \mathrm{kg} \mathrm{CCG}$ & $46.80 \pm 4.56^{* \mathrm{bc}}$ & $56.60 \pm 1.61^{\mathrm{bc}}$ & $120.84 \pm 16.54^{* \mathrm{~b}}$ & $6.33 \pm 0.74^{*}$ & $24.50 \pm 1.87$ \\
$8 \mathrm{mg} / \mathrm{kg} \mathrm{CCG}$ & $22.47 \pm 3.82^{\mathrm{ac}}$ & $45.90 \pm 6.59^{\mathrm{a}}$ & $348.47 \pm 90.70^{* \mathrm{ac}}$ & $6.26 \pm 1.47^{*}$ & $24.83 \pm 2.14$ \\
$16 \mathrm{mg} / \mathrm{kg} \mathrm{CCG}$ & $18.67 \pm 3.16^{*}{ }^{*}$ & $45.54 \pm 6.90^{\mathrm{a}}$ & $90.73 \pm 13.21^{* \mathrm{~b}}$ & $5.56 \pm 0.91^{*}$ & $24.67 \pm 2.80$ \\
\hline
\end{tabular}

The results are shown as mean $\pm \mathrm{SD}(p<0.05)$. For the analysis of data, one-way ANOVA was used. CCG: Croton caudatus Geiseler. *Indicate data showed significant difference with control; a: significant difference with $4 \mathrm{mg} / \mathrm{kg}$ CCG group; b: significant difference with $8 \mathrm{mg} / \mathrm{kg}$ CCG group and; c: significant difference with $16 \mathrm{mg} / \mathrm{kg} \mathrm{CGG}$ group. 
Testosterone hormone is one of the essential reproductive hormones to regulate the spermatogenesis process.(42) Thus, this study has measured the level of testosterone hormone in the serum sample of the rats. The result showed that CCG treatments were significantly improved the level of testosterone if compared to the control group. Finding from this study is in line with the result of the previous study, which showed the aqueous extract of Phyllanthus gomphocarpus Hook. significantly increased the level of testosterone after 21 days of treatment only.(27) The results of the previous study are also in agreement with those of the present study which revealed the histological changes in testicular tissue significantly increased in the groups of rats treated with CCG roots extract for 21 days. However, the higher concentration of CCG treatment $(8 \mathrm{mg} / \mathrm{kg}$ and $16 \mathrm{mg} / \mathrm{kg}$ ) showed significantly decreased of testosterone level when compared to the lowest concentration (4 mg/ $\mathrm{kg}$ ) of CCG roots extract treatment. Leydig cell dysfunction and suppression of testosterone levels were associated with spermatogenic damage and can be seen in the disruption of the histological structure of the testicular tissue.(43) These showed that the other parameters also essential to be associated with determining the effects of CCG on male fertility. Even this study found that the lower level of testosterone detected in the higher concentration of CCG group, the results from sperm parameters and histological structure of the testes were essential to be assessed to determine the concentration of CCG that can give the best effects on male fertility.

Hepatoxicity tests or liver function tests were performed to evaluate the effects of the CCG roots extract to the liver of the treated rats. The tests performed were ALT and AST. ALT is found primarily in the liver and significantly increased in serum ALT level indicate a liver problem such as necrosis.(44) For the AST, it is an enzyme that's present in various tissues of the body. AST is found in the highest concentrations in the liver, muscles, heart, kidney, brain and red blood cells, but it is in a small amount of in the bloodstream. Higher amounts of AST in the blood can be associated with liver injury.(45) In this study, results showed that the ALT and AST levels in all the treated group were below the control group, except in the middle group of $8 \mathrm{mg} / \mathrm{kg}$. These results indicate that CCG roots do not give adverse effects to the liver.

Nephrotoxicity tests, or kidney function test were evaluated to assess the effects of CCG roots on the kidney of the rats. The tests performed are creatinine and BUN level using the serum as a sample. Creatinine and BUN are the specific parameters to assess renal profile. In the assessment, results showed that the creatinine and BUN levels are lower than the control group. These findings show that the treatment of CCG roots does not disrupt the normal function of the kidney. Akintunde and colleagues demonstrated that phenolics compounds from Croton zambiscus leaves have renoprotective property against chronic mixed-metal induced-nephrotoxicity.(29) Hence, this suggests that CCG roots extract also has a renoprotective ability.

Finally, the main limitations of this study were the absence of oxidative stress analysis with DNA damage analysis and the lack of molecular studies to determine the impacts of CCG root extract on testicular function and sperm properties in rats. The molecular mechanisms underlying the enhancement effects of CCG on rat testicles and sperm should be considered in future research.

\section{Conclusion}

In conclusion, the administration of $4 \mathrm{mg} / \mathrm{kg} \mathrm{CCG}$ root extract improves spermatogenic activity within the seminiferous tubules in Wistar rats without any hepatotoxicity and nephrotoxicity effect on the liver and kidney.

\section{Acknowledgements}

This research was funded by the Ministry of Higher Education (MOHE) of Malaysia through RAGS Grant (No: 600-RMI/RAGS 5/3 (45/2014). The authors acknowledge all staff, colleagues and several students at the Natural Product \& Phytomedicine Biotechnology Research Laboratory (NPPBRL), Faculty of Health Sciences, Universiti Teknologi MARA Selangor, Puncak Alam Campus especially the RIG 7 members for their contribution and assistance throughout this study.

\section{References}

1. Organisation for Economic Co-operation and Development. Fertility. In: Society at a Glance 2019. Paris: OECD; 2019. p. 76-7.

2. World Government Summit. Government in 2071 Guidebook: Preparing for New Frontiers. Dubai: World Government Summit. 2018

3. Zegers-Hochschild F, Adamson GD, de Mouzon J, Ishihara O, Mansour R, Nygren K, et al. The International Committee for Monitoring Assisted Reproductive Technology (ICMART) and the World Health Organization (WHO) Revised Glossary on ART Terminology, 2009. Hum Reprod. 2009; 24: 2683-7. 
4. Nieschlag E, Lenzi A. The conventional management of male infertility. Int J Gynecol Obstet. 2013; 123: S31-5.

5. Brezina PR, Yunus FN, Zhao Y. Effects of pharmaceutical medications on male fertility. J Reprod Infertil. 2012; 13: 3-11.

6. Plaseski T, Noveski P, Popeska Z, Efremov GD, Plaseska-Karanfilska D. Association study of single-nucleotide polymorphisms in FASLG, JMJDIA, LOC203413, TEX15, BRDT, OR2W3, INSR, and TAS2R38 genes with male infertility. J Androl. 2012; 33: 67583.

7. Barratt CLR, Björndahl L, Menkveld R, Mortimer D. ESHRE special interest group for andrology basic semen analysis course: A continued focus on accuracy, quality, efficiency and clinical relevance. Hum Reprod. 2011; 26: 3207-12.

8. Malviya N, Jain S, Gupta VB, Vyas S. Recent studies on aphrodisiac herbs for the management of male sexual dysfunction - A review. Acta Pol Pharm Drug Res. 2011; 68: 3-8.

9. Pasqualotto FF, Lucon AM, Sobreiro BP, Pasqualotto EB, Arap S. Effects of medical therapy, alcohol, smoking, and endocrine disruptors on male infertility. Rev Hosp Clin Fac Med Sao Paulo. 2004; 59: 375-82.

10. Zhang C, Wang A, Sun X, Li X, Zhao X, Li S, et al. Protective effects of Lycium barbarum polysaccharides on testis spermatogenic injury induced by bisphenol a in mice. Evid Based Complement Alternat Med. 2013; 2013: 690808. doi: 10.1155/2013/690808.

11. Kokilavani P, Suriyakalaa U, Elumalai P, Abirami B, Ramachandran $\mathrm{R}$, Sankarganesh A, et al. Antioxidant mediated ameliorative steroidogenesis by Commelina benghalensis L. and Cissus quadrangularis L. against quinalphos induced male reproductive toxicity. Pestic Biochem Physiol. 2014; 109: 18-33.

12. Kasote DM, Katyare SS, Hegde MV, Bae H. Significance of antioxidant potential of plants and its relevance to therapeutic applications. Int J Biol Sci. 2015; 11: 982-91.

13. Nantia EA, Moundipa PF, Monsees TK, Carreau S. Medicinal plants as potential male anti-infertility agents: a review. Basic Clin Androl. 2009; 19: 148-58.

14. Ramasamy S, Wahab NA, Abidin NZ, Manickam S. Cytotoxicity evaluation of five selected Malaysian Phyllanthaceae species on various human cancer cell lines. J Med Plants Res. 2011; 5: 226773.

15. Gupta S, Pereira L, Dugar R, Patil R. Polysaccharides from aloe leaf mucilage as potential immunological-based anti-fertility agents. Int J Pharm Sci Res. 2013; 4: 440-4.

16. Tellería MC, Sancho G, Funk VA, Ventosa I, Roque N. Pollen morphology and its taxonomic significance in the tribe Gochnatieae (Compositae, Gochnatioideae). Plant Syst Evol. 2013; 299: 935-48.

17. Morgan AM, El-Ballal SS, El-Bialy BE, El-Borai NB. Studies on the potential protective effect of cinnamon against bisphenol A- and octylphenol-induced oxidative stress in male albino rats. Toxicol Rep. 2014; 1: 92-101.

18. Nath R, Roy S, De B, Choudhury MD. Anticancer and anti oxidant activities of Croton : A Review. Int J Pharm Pharm Sci. 2013; 5: 6370.

19. Buragohain J. Ethnomedicinal plants used by the ethnic communities of Tinsukia district of Assam, India. Recent Res Sci Technol. 2011; 3: $31-42$

20. Priya G, Saravanan K, Renuka C. Medicinal plants with potential antifertility activity- A review of sixteen years of herbal medicine research (1994-2010). Int J PharmTech Res. 2012; 4: 481-94.

21. Mat-Salleh K, Latiff A. Tumbuhan ubatan Malaysia. First. Bangi: Pusat Pengurusan Penyelidikan, UKM; 2002.

22. Samuel AJSJ, Kalusalingam A, Chellappan DK, Gopinath R, Radhamani S, Husain HA, et al. Ethnomedical survey of plants used by the Orang Asli in Kampung Bawong, Perak, West Malaysia. J Ethnobiol Ethnomed. 2010; 6: 5. doi: 10.1186/1746-4269-6-5.

23. Subhaswaraj P, Sowmya M, Bhavana V, Dyavaiah M, Siddhardha B. Determination of antioxidant activity of Hibiscus sabdariffa and Croton caudatus in Saccharomyces cerevisiae model system. J Food Sci Technol. 2017; 54: 2728-36.

24. Wang Y, Zou ZM. Sesquiterpenes from the Stems of Croton caudatus Geisel. var. tomentosus Hook. Chin J Nat Med. 2016; 6: 339-41.

25. Nabavi N, Todehdehghan F, Shiravi A. Effect of caffeine on motility and vitality of sperm and in vitro fertilization of outbreed mouse in T6 and M16 media. Iran J Reprod Med. 2013; 11: 741-6.

26. Jahan S, Ain QU, Ullah H. Therapeutic effects of quercetin against bisphenol A induced testicular damage in male Sprague Dawley rats. Syst Biol Reprod Med. 2016; 62: 114-24.

27. Bahari EA, Ismail MAH, Dasiman R, Haron N, Amom Z. The effects of phyllanthus gomphocarpus Hook. F. aqueous extract supplementation on androgenic hormonal level and histological testes morphometry. J Teknol. 2016; 78: 55-60.

28. Ceriotti F, Henny J, Queraltó J, Ziyu S, Özarda Y, Chen B, et al. Common reference intervals for aspartate aminotransferase (AST), alanine aminotransferase (ALT) and $\gamma$-glutamyl transferase (GGT) in serum: results from an IFCC multicenter study. Clin Chem Lab Med. 2010; 48: 1593-601.

29. Akintunde JK, Ayeni SA, Adeoye MA, Shittu AO. Rat liver and kidney post-mitochondrial dysfunction by addition of chronic mixed metal intoxication and hepatorenal wellness mediated by phenolic components from Croton zambiscus leaves. Environ Toxicol Pharmacol. 2020; 74: 103293. doi: 10.1016/j.etap.2019.103293.

30. European Committee For Clinical Laboratory Standards (ECCLS). Determination of the catalytic activity concentration in serum of L-aspartate aminotransferase (EC 2.6.1.1, ASAT). Klin Chem Mitt. 1989; 20: 198-204.

31. Bergmeyer HU, Horder M, Rey J. Approved recommendation on IFCC methods for the measurement of catalytic enzymes. Part 3: IFCC method for alanine aminotransferase. J Clin Chem Clin Biochem. 1986; 24: 481-95.

32. European Committee For Clinical Laboratory Standards (ECCLS). Determination of the catalytic activity concentration in serum of L-alanine aminotransferase (EC 2.6.1.2, ALAT). Klin Chem Mitt. 1989; 20: 204-11.

33. Burtis CA, Bruns DE. Urea. In: Tietz Fundamentals of Clinical Chemistry and Molecular Diagnostics. 2015. p.368-70.

34. Jaffé M. Ueber den Niederschlag, welchen Pikrinsäure in normalem Harn erzeugt und über eine neue Reaction des Kreatinins. Zeitschrift für Physiol Chemie. 1886; 10: 391-400.

35. Delanghe JR, Speeckaert MM. Creatinine determination according to Jaffe - What does it stand for? NDT Plus. 2011; 4: 83-6.

36. Morakinyo AO, Iranloye BO, Daramola AO, Adegoke OA. Antifertility effect of calcium channel blockers on male rats: association with oxidative stress. Adv Med Sci. 2011; 56: 95-105.

37. Zou GA, Su ZH, Zhang HW, Wang Y, Yang JS, Zou ZM. Flavonoids from the stems of Croton caudatus Geisel. var. tomentosus Hook. Molecules. 2010; 15: 1097-102.

38. Bahmanpour S, Talaei T, Vojdani Z, Panjehshahin MR, Poostpasand A, Zareei MG, et al. Effect of Phoenix Dactylifera Pollen on Sperm. 2006; 31: 208-12.

39. Vosoughi S, Khavanin A, Salehnia M, Mahabadi HA, Shahverdi A, Esmaeili V. Adverse effects of formaldehyde vapor on mouse sperm parameters and testicular tissue. 2013; 6: 250-7.

40. Abbasi Z, Tabatabaei SRF, Mazaheri Y, Barati F, Morovvati H. Effects of sesame oil on the reproductive parameters of diabetes mellitusinduced male rats. World J Mens Health. 2013; 31: 141-9. 
41. Creasy DM. Evaluation of testicular toxicity in safety evaluation studies: the appropriate use of spermatogenic staging. Toxicol Pathol. 1997; 25: 119-31.

42. Roberts KP, Chauvin TR. Molecular mechanisms of testosterone action on the testis. Curr Opin Endocr Metab Res. 2019; 6: 29-33.

43. Ge R, Chen G, Hardy MP. The role of the leydig cell in spermatogenic function. In: Cheng CY, editor. Molecular Mechanisms in Spermatogenesis. New York: Springer; 2008. p.255-69.

44. Liu Z, Que S, Xu J, Peng T. Alanine aminotransferase-old biomarker and new concept: A review. Int J Med Sci. 2014; 11: 925-35.

45. McGill MR. The past and present of serum aminotransferases and the future of liver injury biomarkers. EXCLI J. 2016; 15: 817-28. 